\title{
CBFB wt Allele
}

National Cancer Institute

\section{Source}

National Cancer Institute. CBFB wt Allele. NCI Thesaurus. Code C52523.

Human CBFB wild-type allele is located in the vicinity of $16 q 22.1$ and is approximately 72 $\mathrm{kb}$ in length. This allele, which encodes core-binding factor subunit beta protein, plays a role in the mediation of transcription. Acute myeloid leukemia of the M4Eo subtype is linked to the occurrence of a chromosomal inversion inv(16)(p13;q22), which fuses this gene to the MYH11 gene. 